\title{
Blood Toxic Element Levels in Children from South Coastal Andhra Pradesh
}

\author{
Vijaya Sarathi ${ }^{1}$ (I) $\cdot$ Ramisetty Umamahesh ${ }^{2} \cdot$ Md. Hafiez Ahmed $^{2} \cdot$ Kajal Rai $^{3} \cdot$ Hulivana Boranna Chaithanya $^{4}$
}

Received: 13 September 2020 / Accepted: 24 November 2020 / Published online: 27 November 2020

(C) Dr. K C Chaudhuri Foundation 2020

To the Editor: Several studies have reported blood-lead levels in Indian children but the data regarding the blood levels of other toxic elements in Indian children are limited. Hence, we have evaluated the blood levels of toxic elements in children from south coastal Andhra Pradesh. Thirty-five apparently healthy children aged 3-18 y were included in this crosssectional study conducted at Narayana Medical College, Nellore. Fasting blood samples were analyzed for blood levels of toxic elements and serum calcium. The elevated toxic element level was defined as a level above the upper limit of normal (ULN) as per the manufacturer's data. The ULN for blood aluminum, lead, silver, and strontium were 30, 150, 4, and $38 \mu \mathrm{g} / \mathrm{L}$, respectively.

The age of the study population was $11.86 \pm 4.30 \mathrm{y}$ and 21 participants were boys. The mean \pm SD (range) blood lead, aluminium, silver, and strontium levels were $21.68 \pm$ $7.11 \mu \mathrm{g} / \mathrm{L}$ (9.65-41.05), $60.53 \pm 42.04$ (16.33-208.08), 2.43 $\pm 2.13(0.64-12.50)$ and $50.56 \pm 18.51(22.87-106.98) \mu \mathrm{g} / \mathrm{L}$, respectively. The blood lead, aluminum, silver, and strontium levels were elevated in two, four, six, and 20 participants, respectively. All elevations were less than three-fold above the ULN and none of them had any manifestations of toxicity. The blood levels of antimony, arsenic, barium, beryllium, bismuth, cadmium, cesium, mercury, thallium, tin, and uranium levels were normal in all children. Blood strontium level had a

Vijaya Sarathi

drvijayasarathi@gmail.com

1 Department of Endocrinology, Vydehi Institute of Medical Sciences and Research Center, Bengaluru, Karnataka, India

2 Department of Pediatrics, Narayana Medical College and Hospital, Andhra Pradesh Nellore, India

3 Analytical Chemistry Division, Thyrocare Technologies Limited, Navi Mumbai, Maharashtra, India

4 Department of Endocrinology, Narayana Medical College and Hospital, Nellore, Andhra Pradesh, India significant positive correlation with serum calcium $(\mathrm{r}=0.41$, $p=0.017$ ).

Elevated blood strontium level in the study participants is most likely due to increased intake of strontium-containing seafood; however, the contribution from the release of strontium into the environment from a nearby rocket launch center needs evaluation $[1,2]$. Similar biological, chemical and pharmacokinetic properties of strontium and calcium explain the positive correlation in their blood levels [3]. This property of strontium also leads to the predominant accumulation of strontium in bone and teeth. Although blood-strontium levels were only modestly elevated in the blood, accumulation of the element in bones may be disproportionately larger. Strontium ranelate has been used to improve bone mineral density in adults with osteoporosis [4]. However, higher concentrations in growing bones may seriously affect bone development [5].

\section{Compliance with Ethical Standards}

Conflict of Interest None.

\section{References}

1. https://www.atsdr.cdc.gov/PHS/PHS.asp?id=654\&tid=120. Accessed on 01.11.2020.

2. https://www.slashgear.com/nasa-fired-rockets-into-the-northernlights-for-this-epic-aurora-show-08572405/. Accessed on 01.11 . 2020.

3. Wasserman RH. Strontium as a tracer for calcium in biological and clinical research. Clin Chem. 1998;44(3):437-9.

4. Reginster JY, Brandi ML, Cannata-Andía J, et al. The position of strontium ranelate in today's management of osteoporosis. Osteoporos Int. 2015;26(6):1667-71.

5. https://www.atsdr.cdc.gov/toxprofiles/tp159-c3.pdf. Accessed on 01.11.2020.

Publisher's Note Springer Nature remains neutral with regard to jurisdictional claims in published maps and institutional affiliations. 